УДК 336.143.2:352

Лактіонова О.А. д.е.н., проф. Донецького національного університету імені Василя Стуса

Лемешко М.O. магістр Донецького національного університету імені Василя Стуса

\title{
ФІНАНСОВЕ СТИМУЛЮВАННЯ РОЗВИТКУ МАЛОГО І СЕРЕДНЬОГО БІЗНЕСУ В МІСТАХ УКРАЇНИ: АНАЛІЗ ТА ОЦІНКА ЕФЕКТИВНОСТІ
}

В статті розглянуто проблему доступу до фінансових ресурсів малих та середніх підприємств в Україні, законодавче регулювання механізмів та методів фінансового стимулювання розвитку малого та середнього підприємництва, а також механізми такої підтримки в містах України. Досліджено стан розвитку сектору малого та середнього підприємництва, його структуру та стан фінансових можливостей таких підприємств в регіонах України. Проведено аналіз сучасного стану розвитку малого та середнього підприємництва в містах України використовуючи інформацію Державної служби статистики України та відкриті дані, надані відповідними виконавчими органами місцевого самоврядування, а саме 5 міст: Вінниці, Кропивницького, Рівного, Чернівців та Чернігова. Проаналізовано інструменти, обсяги фінансування нормативно-правових актів та особливості механізмів фінансової стимулювання розвитку малого та середнього підприємництва в містах. Визначено основні відмінності у підходах до фінансової підтримки підприємництва та проаналізовано ефективність інструментів.

Ключові слова: підприємництво, малий та середній бізнес, фінансова підтримка, стимулювання розвитку бізнесу

Рис. 6, Табл. 5, Літ. 11.

Лактионова А.А., Лемешко М.О.

\section{ФІНАНСОВЕ СТИМУЛЮВАННЯ РОЗВИТКУ МАЛОГО І СЕРЕДНЬОГО БІЗНЕСУ В МІСТАХ УКРАЇНИ: АНАЛІЗ ТА ОЦІНКА ЕФЕКТИВНОСТІ}

В статье рассмотрена проблема доступа к финансовым ресурсам малых и средних предприятий в Украине, законодательное регулирование механизмов и методов финансового стимулирования развития малого и среднего предпринимательства, а также механизмы такой поддержки в городах Украины. Исследовано состояние развития сектора малого и среднего предпринимательства, его структуру и состояние финансовых возможностей таких предприятий в регионах Украины. Проведен анализ современного состояния развития малого и среднего предпринимательства в городах Украины используя информацию Государственной службы статистики Украины и открытые данные, предоставленные соответствующими исполнительными органами местного самоуправления, а именно 5 городов: Виннице, Кропивницкого, Ровно, Черновцов и Чернигова. Проанализированы инструменты, объемы финансирования нормативно-правовых актов и особенности механизмов финансовой стимулирования развития малого и среднего предпринимательства в городах. Определены основные различия в подходах к финансовой поддержке предпринимательства и проанализирована эффективность инструментов.

Ключевые слова: предпринимательство, малый и средний бизнес, финансовая поддержка, стимулирование развития бизнеса 
Laktionova A., Lemechko M.

\section{FINANCIAL IMPLICATIONS FOR THE DEVELOPMENT OF SMALL AND MEDIUM BUSINESS IN CITIES OF UKRAINE: ANALYSIS AND EVALUATION OF EFFICIENCY}

The article considers the problem of access to financial resources of small and mediumsized enterprises in Ukraine, legislative regulation of mechanisms and methods of financial incentives for the development of small and medium-sized businesses, as well as mechanisms for such support in the cities of Ukraine. The state of development of the small and mediumsized business sector, its structure and the state of the financial capabilities of such enterprises in the regions of Ukraine are investigated. The analysis of the current state of development of small and medium-sized businesses in the cities of Ukraine using information from the State Statistics Service of Ukraine and open data provided by the relevant executive bodies of local self-government, namely 5 cities: Vinnitsa, Kropyvnytskyi, Rovno, Chernivtsi and Chernihiv. Analyzed the tools, the volume of financing of legal acts and features of mechanisms for financial incentives for the development of small and medium-sized businesses in cities. The main differences in the approaches to financial support of entrepreneurship are determined and the effectiveness of the tools is analyzed.

Key words: entrepreneurship, small and medium business, financial support, business development stimulation

Постановка проблеми. Підприємництво сьогодні безпосередньо пов'язано 3 ризиком та пошуком інновацій, тож проблематика стимулювання та підтримки його розвитку є актуальною, особливо для малих та середніх підприємців які не мають достатньо міцного фінансового ресурсу для свого сталого розвитку. Наразі малі і середні підприємства (надалі - МСП) бачать одну 3 найголовніших перешкод для розширення - брак фінансових можливостей. Розуміючи необхідність побудови місцевої економіки саме на сучасних принципах конкурентоспроможності, на регіональному та загальнодержавному рівнях, і маючи зростаючий фінансовий ресурс, місцеві органи влади починають приділяти все більшу увагу малому та середньому підприємництву та впроваджувати фінансові механізми їх підтримки. В свою чергу інструментарій органів місцевого самоврядування щодо фінансового стимулювання МСП, який регламентує законодавство, є широким та чітко не визначеним. Достатньо високим $\epsilon$ ризик неефективного використання бюджетних коштів на фінансову підтримку МСП, невисокої результативності обраних елементів такого механізму.

Аналіз останніх досліджень і публікацій. Дослідженням механізмів державного фінансового стимулювання розвитку суб'єктів господарювання займалися такі науковці, як В.Гончарова, Р.Данилейчук, І.Драган, І.Комарова. Значний внесок у розвиток теоретичних і практичних аспектів фінансової політики на державному i місцевому рівнях щодо підтримки розвитку сектору МСП зробили також такі науковці 3. Варналій, С. Волосович, В. Герасименко, В. Патрушевська, Л. Воротіна, В. Гаврилюк, О. Ганенко, В. Геєць, Л.Дмитриченко, В. Жук.

Метою статті $є$ визначення стану розвитку МСП та видів його фінансового стимулювання в розрізі регіонів та міст України, аналіз і оцінка ефективності механізмів фінансового стимулювання розвитку МСП.

Виклад основного матеріалу дослідження. Україна, знаходячись у стані структурних перетворень в економіці, повинна шукати джерела динамічних трансформацій, що дадуть суттєвий поштовх до розвитку країни та іiі 
конкурентоспроможності економіки. На нашу думку, одним з таких джерел може стати мале та середнє підприємництво, а його підтримка та розвиток одним 3 пріоритетних завдань державної політики. Адже МСП має характеристики, які релевантні сьогоденню, а саме маневреність, гнучкість, швидкість прийняття рішень, інноваційність і вони стають вирішальними факторами перемоги у конкурентній боротьби в сучасних загальносвітових реаліях. Актуалізація розвитку механізму фінансового стимулювання розвитку малого і середнього бізнесу на локальному рівні визначається наступними чинниками: по-перше, значимістю цього сектору ділової активності у соціально-економічному розвитку регіону, формуванні його фіскального та, зокрема, податкового потенціалу; по-друге, поступове зростання фінансових можливостей на регіональному рівні як основи для забезпечення функціонування ефективного локального фінансового механізму розвитку малого і середнього бізнесу.

Українське законодавство, а саме стаття 55 Господарського кодексу, доволі чітко дефінує поняття підприємств за розміром та дає чіткі рамки залежно від кількості працюючих та доходів від будь-якої діяльності за рік. Так, до малого підприємництва слід відносити суб'єктів господарювання, в тому числі мікро підприємництва, які мають до 50 осіб працівників та річних дохід до 10 млн. євро, а також до середнього підприємництва суб'єктів господарювання, що мають до 250 осіб працівників та річний дохід до 50 млн. євро [1]. Узагальнення законодавчого регламентування напрямів та методів фінансового стимулювання наведено у табл. 1.

Таблиця 1 - Напрями та методи фінансового стимулювання розвитку малого та середнього підприємництва, які можуть застосовувати органи місцевого самоврядування щодо розвитку місцевого бізнесу

\begin{tabular}{|c|c|c|c|}
\hline \multirow[b]{2}{*}{ Група } & Напрями & \multicolumn{2}{|c|}{ Методи } \\
\hline & \multicolumn{2}{|c|}{$\begin{array}{c}\text { ЗУ «Про розвиток та державну підтримку малого і середнього } \\
\text { підприсмництва в Україні» }\end{array}$} & $\begin{array}{l}\text { ЗУ «Про державну допомогу } \\
\text { суб'єктам господарювання» }\end{array}$ \\
\hline $\begin{array}{c}\text { Пряма } \\
\text { фінансова } \\
\text { підтримка }\end{array}$ & $\begin{array}{l}\text { • Забезпечення фінансової } \\
\text { державної підтримки малих і } \\
\text { середніх підприємств шляхом } \\
\text { запровадження державних } \\
\text { програм кредитування, } \\
\text { надання гарантій для } \\
\text { отримання кредитів, часткової } \\
\text { компенсації відсоткових ставок } \\
\text { за кредитами тощо }\end{array}$ & $\begin{array}{l}\text { • Часткова компенсація } \\
\text { відсоткових ставок за кредитами } \\
\text { • Часткова компенсація лізингових, } \\
\text { факторингових платежів та платежів } \\
\text { за користування гарантіями } \\
\text { • Надання гарантії та поруки за } \\
\text { кредитами суб'єктів МСП } \\
\text { • Надання кредитів, для } \\
\text { започаткування діяльності } \\
\text { • Надання позик на придбання і } \\
\text { впровадження нових технологій } \\
\text { • Компенсація видатків на розвиток } \\
\text { кооперації між суб'єктами МСП та } \\
\text { великими підприємствами; }\end{array}$ & $\begin{array}{l}\text { •Надання субсидій та грантів; } \\
\text { •Надання дотацій } \\
\text { •Надання гарантій, кредитів на } \\
\text { пільгових умовах, } \\
\text { обслуговування кредитів за } \\
\text { пільговими тарифами; }\end{array}$ \\
\hline $\begin{array}{c}\text { Непряма } \\
\text { фінансова } \\
\text { підтримка }\end{array}$ & $\begin{array}{l}\text { - Удосконалення та } \\
\text { спрощення порядку ведення } \\
\text { обліку в цілях оподаткування } \\
\text { • Запровадження спрощеної } \\
\text { системи оподаткування, обліку } \\
\text { та звітності } \\
\text { • Залучення до виконання } \\
\text { науково-технічних і соціально- } \\
\text { економічних програм, } \\
\text { здійснення постачання } \\
\text { продукції для державних та } \\
\text { регіональних потреб }\end{array}$ & & $\begin{array}{l}\text { • Списання боргів, штрафних } \\
\text { санкцій, компенсація збитків } \\
\text { • Надання товарів чи послуг } \\
\text { за цінами нижче ринкових або } \\
\text { придбання товарів чи послуг за } \\
\text { цінами, вище ринкових } \\
\text { • Зменшення фінансових } \\
\text { зобов'язань перед фондами } \\
\text { загальнообов’язкового } \\
\text { державного соціального } \\
\text { страхування }\end{array}$ \\
\hline
\end{tabular}

Джерело: складено на основі [2], [3] 
Органи місцевого самоврядування можуть здійснювати фінансове стимулювання розвитку МСП виключно в правовому полі, функціонуючи в сфері публічного адміністрування та управління. Закон України «Про розвиток та державну підтримку малого і середнього підприємництва в Україні», у Розділі IV по суті визначає напрями та види фінансової підтримки за кошти державного і місцевих бюджетів, а отже, ні рівні міст України [2]. Окрім цього, Законом України «Про державну допомогу суб'єктам господарювання» визначається, що державна допомога суб'єктам господарювання - це підтримка у будь-якій формі суб'єктів господарювання за рахунок ресурсів держави чи місцевих ресурсів.[3].

Аналіз стану розвитку сектору МСП вказує на те, що пропорційно вони займають в Україні приблизно 98\% від загальної кількості підприємств, такий самий рівень спостерігається і в країнах західної Європи. Аналогічний рівень спостерігається і за показником кількості найманих працівників - 75\% загальної кількості. Разом із тим, їх фінансовий стан значно відрізняється від показників європейських МСП. Так, частка обсягу реалізації продукції середніми підприємствами по всіх областях України спостерігається на рівні від $60 \%$ до $80 \%$ обсягу по малим та середнім підприємствам (рис. 1). Однак, якщо поглянути на частку обсягу реалізації продукції МСП в загальній структурі, можна побачити тренд до її зменшення за географічною ознакою з заходу на схід (за винятком Харківської області), що пояснюється історично сформованою структурою регіональної економіки України. Так, найбільшу частку обсягу реалізації продукції МСП в 2016 року мала Рівненська область - 88\%, а найнижчу - Донецька $33 \%$.

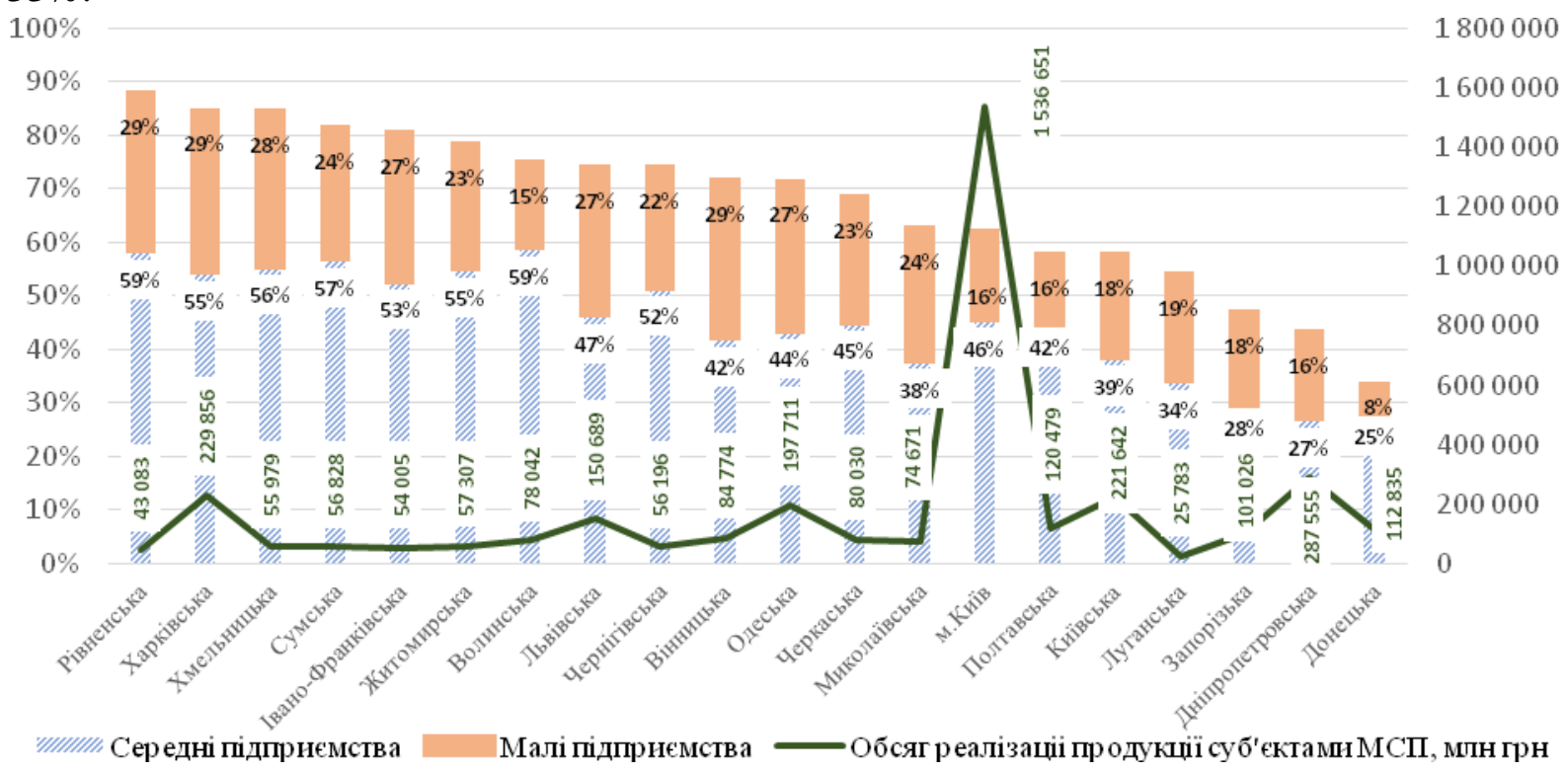

Рисунок 1 - Частка обсягу реалізації продукції малими та середніми підприємствами та обсяги реалізації продукції суб’ єктами МСП по областях України в 2016 році [4]

Аналогічна ситуація спостерігається і за обсягами витрат на оплату праці, де відсоток зменшується у відповідності до географічного положення (рис. 2). 


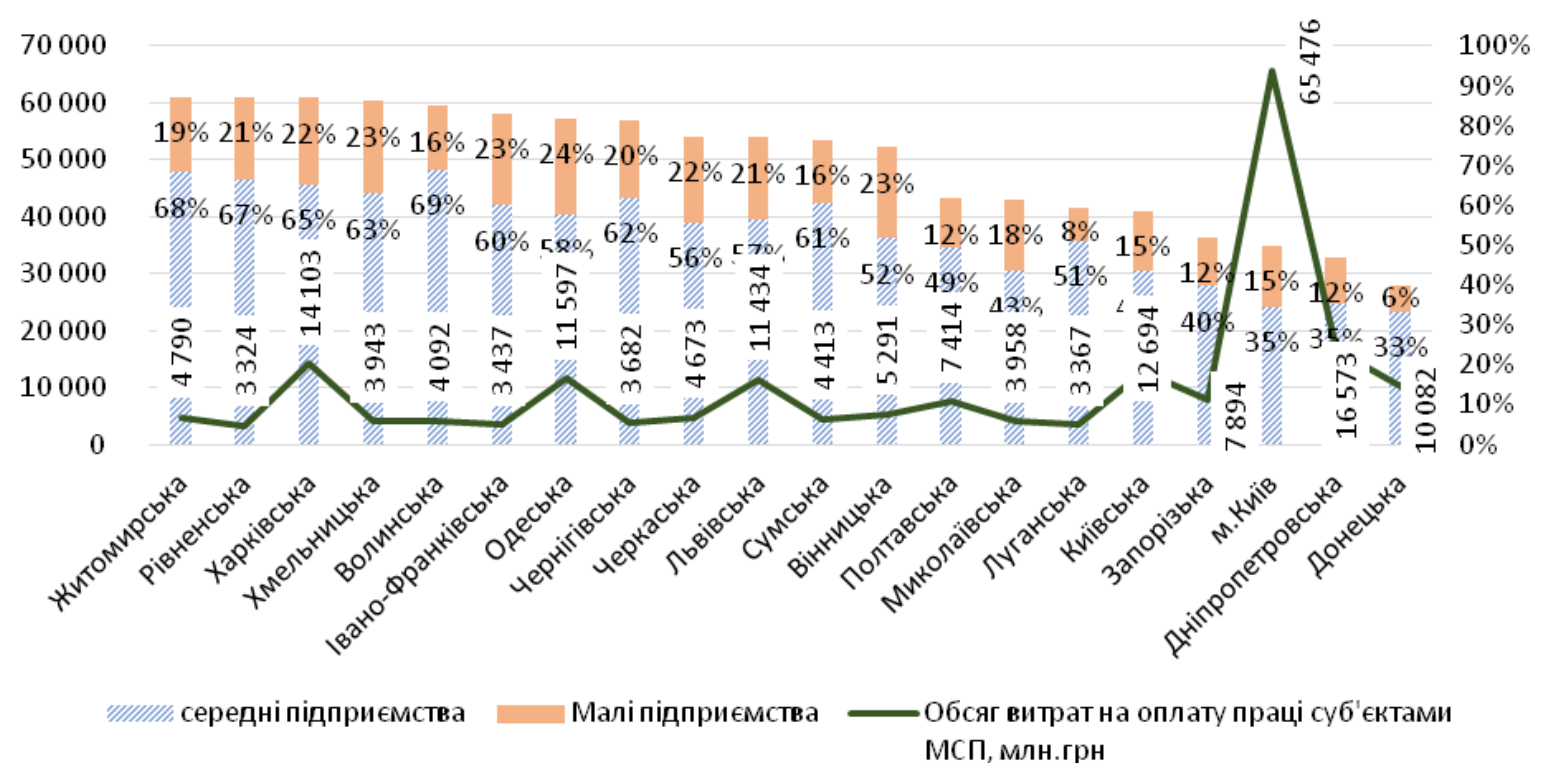

Рисунок 2 - Частка витрат на оплату праці малими та середніми підприємствами та обсяги витрат на оплату праці суб'єктами МСП в областях України в 2016 році [4]

Таким чином, характеризуючи показники стану фінансових можливостей МСП в регіонах України, робимо висновок, що на рівні регіонів чітко прослідковується диференціація розвитку підприємництва в Україні за географічною ознакою. Це несе суттєві ризики для економіки усієї держави, адже робить їі залежною від економічно значущих великих підприємств в окремих регіонах, адже спад галузевої ділової активності можуть сильно вдарити по великим підприємствам та спричинити значний соціально-економічний спад у відповідних регіонах.

Одним із показників ділової активності малих підприємств та, в першу чергу, фізичних осіб-підприємців в містах України, є надходження до бюджету міст єдиного податку (рис.3).

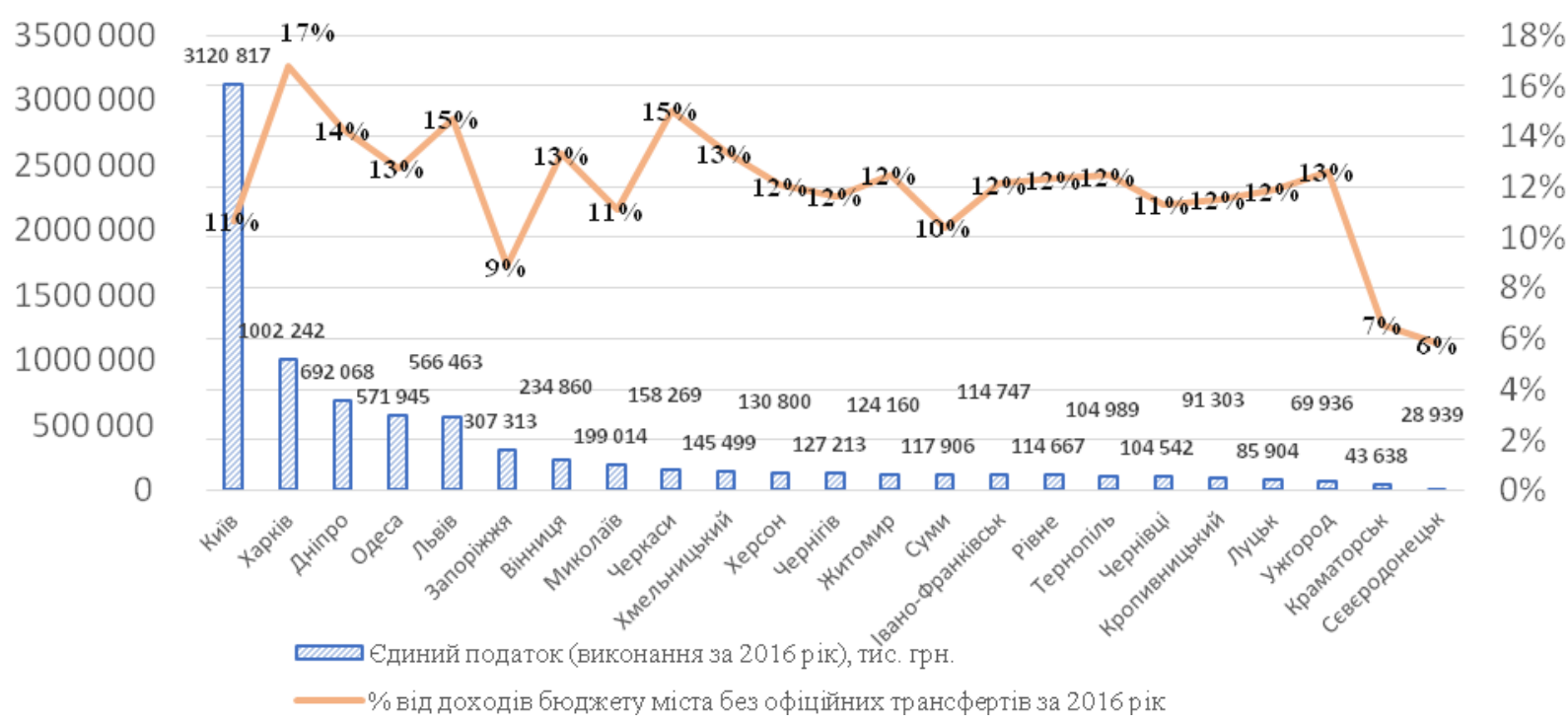

Рисунок 3 - Обсяги сплаченого єдиного податку до місцевих бюджетів міст України та його частка від доходів без урахувань трансфертів за 2016 рік [4] 
Наразі законодавство України регламентує 100\% надходжень сплаченого цього податку до бюджету міст. Аналізуючи обсяги сплаченого податку до місцевих бюджет міст обласного значення можна констатувати, що в містах 3 достатньою часткою малих підприємств лише цей податок забезпечує $14 \pm 3 \%$ відсотка надходжень, що можна побачити на рис. 3.

Таким чином, стан фінансових можливостей МСП в регіонах відрізняється, в першу чергу, структурою економіки регіону. Найбільша кількість МСП спостерігається в регіонах 3 великими обласними центрами, а ефективна структура прибуткових підприємств - у областях зі стабільною соціально-економічної складовою. Разом з тим, зважаючи на такі показники, як частка обсягу реалізації продукції та частка обсягу витрат на оплату праці за регіонами відносно загального показника по всім видам суб'єктів господарювання, варто зазначити, що розвиток МСП в Україні в значній мірі залежить від історично сформованої диференціації розвитку промисловості та окремих видів підприємств, що зумовило розвиток МСП саме у центральних та західних областях України, на відміну від сходу, де переважала структура зайнятості та обсяг реалізованої продукції на перевагу великих підприємств.

Для більш детального аналізу стану МСП в містах України та діючої політики органів місцевого самоврядування щодо фінансового стимулювання розвитку підприємництва візьмемо до аналізу наступні міста: Вінниця, Кропивницький, Рівне, Чернівці та Чернігів, а також відкриті дані, надані відповідними виконавчими органами місцевого самоврядування. Вибір саме таких міст України обумовлено їх різним географічним розташуванням, наявністю програмних документів 3 підтримки та розвитку МСП та заходів з фінансового стимулювання МСП, а також співставними показниками населення (станом на 1 січня 2017 року за даними Державної служби статистики України): м. Вінниця - 372672 особи; м. Кропивницький - 229632 особи; м. Рівне - 247356 осіб; м. Чернівці - 266034 особи; м. Чернігів - 291641 особа.

Динаміка кількості суб'єктів малого та середнього підприємництва наведених міст, інформація про яких відображена на рис. 4., свідчить про чіткий спад кількості суб'єктів МСП по усій вибірці протягом 2013-2017 років. Така ситуація пояснюється економічною кризою та змінами в податковому законодавстві України, що спричинило різке скорочення фізичних осіб підприємців.

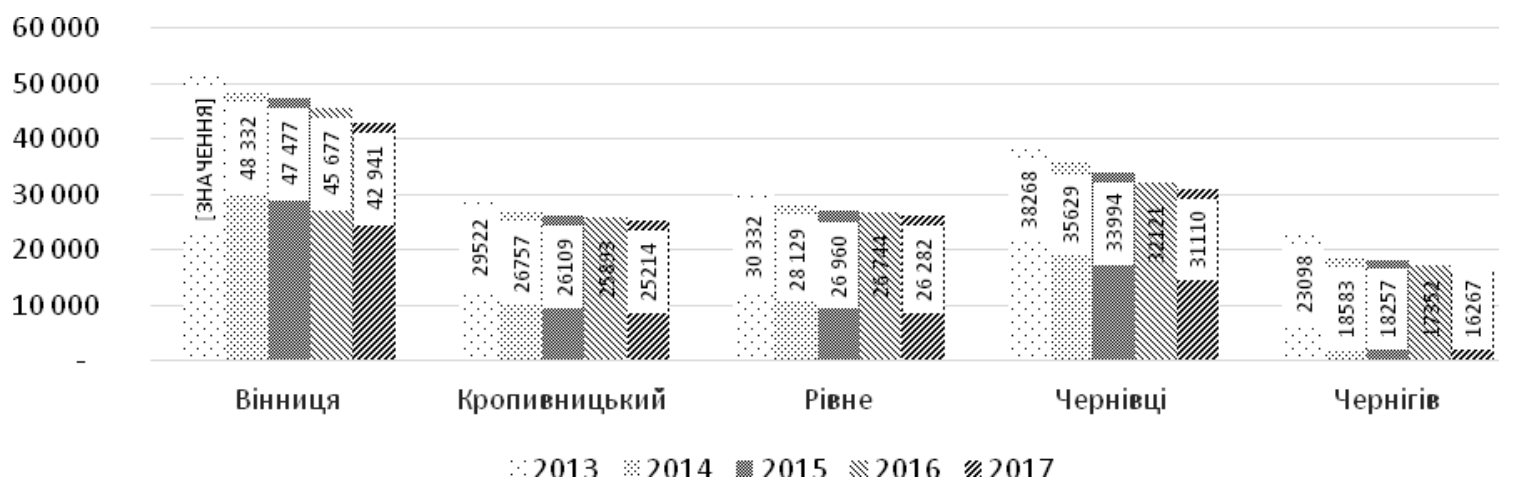

Рисунок 4 - Динаміка кількості суб’єктів МСП в містах за 2013-2017pp. [5-9]

Аналіз обсягу реалізованої продукції суб'єктами малого та середнього підприємництва свідчить, що з 2013 по 2016 рік тренд до зростання обсягу реалізованої продукції зберігався у Вінниці, Кропивницькому, Чернівцях та Чернігові (рис.5). 


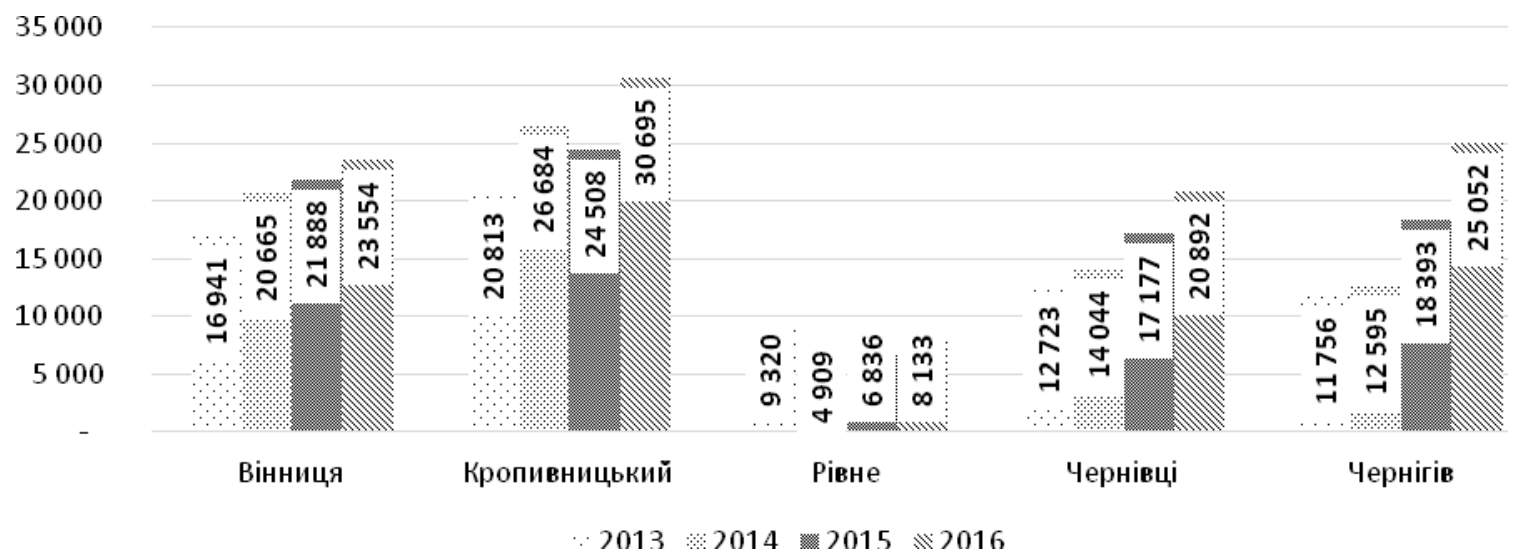

Рисунок 5 - Обсяг реалізованої продукції суб’єктами малого та середнього підприємництва в містах по роках, млн. грн. [5-9]

Як показано на рис. 2.1, кількість суб’єктів МСП станом на 2016 в містах Вінниця та Чернівці значно переважало показник за містом Чернігів, в той же час показник обсягу реалізації продукції МСП міста Чернігів є меншим лише за той же показник по місту Кропивницький.

Показником, який більш прозоро говорить про активність МСП в містах, є обсяг сплаченого єдиного податку до міського бюджету (рис. 6), адже згідно законодавства його платниками можуть бути виключно суб'єкти МСП та $100 \%$ його сплати надходить до місцевих бюджетів.

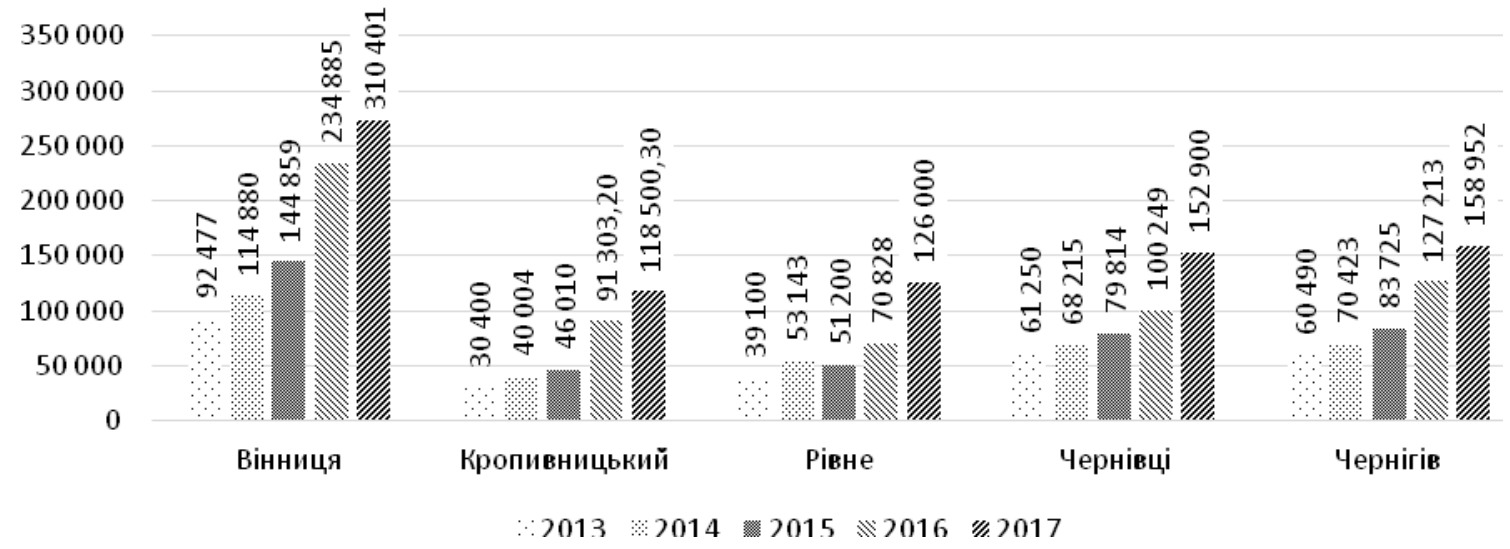

Рисунок 6 - Надходження від сплати суб'єктами МСП єдиного податку до міського бюджету по роках, тис. грн. [5-9]

Роль МСП в містах також характеризується кількістю створених робочих місць. В досліджених містах частка зайнятих у МСП є нерівномірною. Так у Чернівцях та Вінниці станом на 2017 рік відсоток зайнятих у малому та середньому підприємництві складає 15\% та 16\% відповідно від загальної кількості населення, у Чернівцях - 20\%, а в Кропивницькому - 33\%.

Посилення ролі МСП в містах України змушує органи місцевого самоврядування, які перш за все зацікавлені в розвитку місцевого бізнесу, запроваджувати механізми фінансової підтримки місцевого бізнесу. В табл. 2 відображені діючі програмні документи, присвячені саме цьому питанню по вказаних містах. 
Таблиця 2 - Діючі програмні документи, що регламентують стимулювання розвитку та підтримку МСП в містах

\begin{tabular}{|l|l|}
\hline Місто & Назва програмного документу \\
\hline Вінниця & Програма посилення конкурентоспроможності МСП міста Вінниці на 2017-2020 роки \\
\hline Кропивницький & Програма розвитку МСП міста Кіровограда на 2016-2020 роки \\
\hline Рівне & Програма розвитку МСП в місті Рівному на 2018 -2019 роки \\
\hline Чернівці & Програма розвитку МСП в місті Чернівцях на 2017-2018 роки \\
\hline Чернігів & Програма підтримки МСП у місті Чернігові на 2017-2020 роки \\
\hline
\end{tabular}

Джерело: [5-9]

В таблиці 3 наведені дані щодо обсягу фінансування програмних документів (заходів, проектів) з підтримки малого та середнього підприємництва в містах що аналізуються.

Таблиця 3 - Обсяг фінансування заходів з підтримки та розвитку МСП в містах, тис.

\begin{tabular}{|l|r|r|r|r|r|r|}
\hline & \multicolumn{2}{|c}{ ГрН. } \\
\hline Вінниця & $\mathbf{2 0 1 3}$ & $\mathbf{2 0 1 4}$ & $\mathbf{2 0 1 5}$ & \multicolumn{2}{c|}{$\mathbf{2 0 1 6}$} & \multicolumn{2}{c|}{$\mathbf{2 0 1 7}$} & $\mathbf{2 0 1 8}$ \\
\hline Кропивницький & 0,0 & 0,0 & 0,0 & 0,0 & 0,0 & 5734,0 \\
\hline Рівне & 276,4 & 216,2 & 4,5 & 196,7 & 269,8 & 266,0 \\
\hline Чернівці & 4,0 & 0,0 & 9,0 & 33,3 & 15,4 & 400,0 \\
\hline Чернігів & 69,1 & 46,4 & 125,7 & 357,0 & 467,8 & 550,0 \\
\hline
\end{tabular}

Джерело: [5-9]

Програми в своїх заходах та проектах передбачають певні механізми фінансової підтримки МСП. Сам процес фінансового стимулювання та визначення його механізмів $\epsilon$ складним процесом, зазвичай в містах розробляються окремі документи (порядки, положення та ін.) в яких прописується алгоритм, формули та форми фінансового стимулювання МСП, обсяги фінансування таких документів наведено табл. 4.

Таблиця 4 - Фінансування діючих документів що регламентують надання фінансової підтримки МСП в містах

\begin{tabular}{|l|c|c|}
\hline \multirow{2}{*}{ Місто } & \multicolumn{2}{|c|}{ Обсяги фінансування, грн. } \\
\cline { 2 - 3 } & на 2017 рік & на 2018 рік \\
\hline Вінниця & 0 & 5000000 \\
\hline Кропивницький & 100000 & 150000 \\
\hline Рівне & 300000 & 400000 \\
\hline Чернівці & 0 & 0 \\
\hline Чернігів & 981790 (загалом на програму розвитку МСП) & 700000 \\
\hline
\end{tabular}

Джерело: [5-9]

Найпоширенішим способом фінансового стимулювання розвитку МСП $\epsilon$ компенсація відсотків за кредит. Актуальність цього підходу визначається i результатами опитування підприємців. Так, за результатами чергового опитування керівників підприємств (665 респондентів, з яких 71\% - керівники МСП), проведеного Національним банком України у II кварталі 2018 року, найсуттєвішою перешкодою для залучення нових кредитів залишаються високі ставки за кредитами $(65,6 \%$ респондентів), відповідно частка МСП, які планують залучати кредитні кошти є дуже низькою, при цьому саме малі підприємства мають найбільшу потребу в запозиченнях [10]. У Квартальному моніторингу перешкод для розвитку МСП за І квартал 2018 року, 
проведеного Інститутом економічних досліджень та політичних консультацій, зазначається, що представники МСП, зважаючи на те, що НБУ не планує знижувати облікову ставку, найближчим часом не планують залучати кредитні кошти, а саме 72\% малих та 65\% середніх підприємств називають високі процентні ставки основною перешкодою залучення банківського кредиту [11].

Заходи з фінансового стимулювання розвитку МСП передбачають компенсацію відсотків за кредитами у Вінниці, Кропивницькому, Рівному, Чернівцях, а в місті Чернігові діє Положення що відшкодовує витрати на участь у виставково-ярмаркових заходах. Усі нормативно правові акти передбачають процедуру, критерії, механізм визначення розміру та ліміт фінансової підтримки суб'єктам господарювання. Щодо самих механізмів надання фінансової підтримки у містах варто зауважити, що у Кропивницькому, Рівному, Чернівцях та Чернігові фінансова підтримка надається на умовах конкурсного відбору.

Так, у Рівному розпорядженням міського голови створюється Конкурсна комісія до якою можуть входити депутати міської ради, представники виконавчих органів, об'єднань підприємців та ін. За результатами розгляду конкурсної комісії 3 переможцями конкурсу (суб'єктом господарювання), банком (який надав кредит) та Управлінням економіки міста укладається тристоронній договір щодо часткової компенсації відсоткових ставок згідно якого перераховуються кошти на спеціально відкритий рахунок у банку. При цьому зазначено, що Конкурсна комісія сама визначає умови фінансової підтримки, а компенсація відсотків не повинна перевищувати двох облікових ставок НБУ, та складати не більше 100000 грн. в рік на одного позичальника.

У Кропивницькому також передбачений конкурсний відбір суб’єктів підприємницької діяльності, який здійснюється Координаційною радою, до якої можуть входити як представники міської ради так і громадського сектору. Розмір фінансової підтримки, а саме відшкодування відсотків за кредитами, визначається по кожному позичальнику окремо, але не більше 50\% від суми, необхідної для погашення відсотків по кредиту у поточному році. Перерахунок компенсації здійснюється Управлінням економіки міської ради на основі рішення Координаційної ради, на рахунок переможця конкурсу, який відкрито в органах Державної казначейської служби України.

В Положенні, яке регламентує надання фінансової підтримки малим та середнім підприємцям міста Чернігів, також зазначено, що відшкодування витрат підприємств на участь у виставково-ярмаркових заходах (компенсація) здійснюється за рекомендаціями Дорадчого комітету 3 питань підтримки малого та середнього підприємництва у м. Чернігові рішенням виконавчого комітету на розрахунковий рахунок підприємства. Суб'єкти МСП мають право на одну компенсацію протягом календарного року, яка здійснюється у розмірі 30\% від фактичних витрат суб'єкта господарювання на організацією, технічне забезпечення та облаштуванням експозиції, публікації у каталозі, але не більше 50000 грн. у разі очної участі підприємства у виставково-ярмаркових заходах та 5000 грн. у разі заочної участі або публікації у каталозі.

Щодо проекту Положення про умови та порядок надання фінансової підтримки МСП в місті Чернівці передбачається надання такої підтримки на умовах конкурсного відбору, який буде здійснювати спеціальна комісія, що затверджується розпорядженням міського голови. Розмір кредиту отриманого суб'єктом господарювання у банку не може перевищувати 300000 грн, а термін кредитного 
договору - 12 місяців. Зазначимо, що компенсація відсоткових ставок здійснюється лише за умови створення нових робочих місць в розмірах від $30 \%$ до 50\% від загальної суми відсотків за кредитом.

Окремо слід відзначити, що механізм надання фінансової підтримки МСП в місті Вінниця, де фінансова підтримка надається без конкурсної процедури за умови виконання підприємцями попередніх та поточних умов під час користування кредиту, отриманих в банку в рамках процедури компенсації. Сама сума компенсації визначається як різниця в податкових платежах (єдиного податку на ПДФО) суб'єкта господарювання до бюджету міста Вінниці поквартально (поточного року та попереднього кварталу) та диференціюється за терміном користування кредитом. Так у перший рік компенсація складає 75\% суми приросту податкових $\quad$ надходжень, $50 \%$ у другий рік, та $25 \%$ у третій рік за умови вчасної сплати відсотків банку та податків до бюджету.

У таблиці 5 наведено основні відмінності розглянутих механізмів фінансової підтримки малих та середніх підприємств. Відмічаємо, що сам метод надання підтримки за усіма механізмами є надання коштів суб'єктам по факту отримання кредиту у формі дотації 3 місцевого бюджету міста. В свою чергу кардинально відрізняються обмежуючи фактори та задекларована мета надання такої підтримки.

Таблиця 5 - Основні відмінності механізмів фінансової підтримки МСП в містах

\begin{tabular}{|c|c|c|c|}
\hline Місто & $\begin{array}{c}\text { Мета } \\
\text { фінансової підтримка }\end{array}$ & $\begin{array}{c}\text { Механізм } \\
\text { визначення } \\
\text { учасників } \\
\text { процедури } \\
\text { фінансової } \\
\text { підтримки }\end{array}$ & $\begin{array}{l}\text { Обмежуючі фактори } \\
\text { фінансової підтримки }\end{array}$ \\
\hline Вінниця & $\begin{array}{c}\text { Здешевлення вартості користування } \\
\text { кредитом банку, детінізація економіки }\end{array}$ & Автоматично & $\begin{array}{c}\text { Приріст податкових } \\
\text { надходжень поквартально }\end{array}$ \\
\hline Кропивницький & $\begin{array}{c}\text { Здешевлення вартості користування } \\
\text { кредитом }\end{array}$ & Конкурс & $\begin{array}{c}\text { Сума, необхідна для погашення } \\
\text { відсотків по кредиту у п.р. }\end{array}$ \\
\hline Рівне & $\begin{array}{c}\text { Здешевлення вартості користування } \\
\text { кредитом }\end{array}$ & Конкурс & $\begin{array}{c}\text { Не більше } 100000 \text { грн. в рік на } \\
\text { одного позичальника }\end{array}$ \\
\hline Чернівці & $\begin{array}{c}\text { Здешевлення вартості користування } \\
\text { кредитом банку, стимулювання створення } \\
\text { нових робочих місць }\end{array}$ & Конкурс & $\begin{array}{c}\text { Сума кредиту, кількість } \\
\text { створених нових робочих місць }\end{array}$ \\
\hline Чернігів & $\begin{array}{c}\text { Стимулювання участі у виставково- } \\
\text { ярмаркових заходах }\end{array}$ & Конкурс & $\begin{array}{c}\text { Формат участь у виставково- } \\
\text { ярмаркових заходах }\end{array}$ \\
\hline
\end{tabular}

Отже, здійснивши аналіз стану фінансових можливостей МСП в областях України, робимо висновок, що на рівні регіонів чітко прослідковується диференціація розвитку підприємництва в Україні за географічною ознакою. Наголошуючи на загальносвітовій тенденції до зростання ролі міст в економіці країн та беручи до уваги процес децентралізації в Україні до аналізу взято наступні міста: Вінниця, Кропивницький, Рівне, Чернівці та Чернігів. 3 аналізу бачимо дві протилежні картини при порівняні динаміки кількості МСП та обсягу реалізованої продукції у розрахунку на одного суб'єкта малого та середнього підприємництва в міста, суттєве зростання надходжень єдиного податку по всім представленим містам. Проаналізовано наявні діючі програмні документи, що спрямовуються на розвиток та підтримку МСП, їх фінансування. Відзначається, що в усіх таких документах, наявні заходи та проекти, спрямовані на фінансову підтримку МСП, на виконання яких розроблені відповідні 
порядки та положення, що мають фінансування на поточний та минулий 2017 рік, а основною формою фінансової підтримки $є$ - компенсація відсотків за кредитами

Щодо оцінки ефективності наведених вище механізмів фінансового стимулювання малого та середнього підприємництва слід зауважити, що вбачається за можливе оцінка лише по місту Вінниця, Рівне, Чернігів та Кропивницький, адже проект нормативно-правового акту в місті Чернівці, який буде регламентувати вважається таким, що підпадає про законодавство щодо регуляторної політики та наразі (станом на 2018 рік) проходить процедуру прийняття регуляторного акту.

В місті Рівному в рамках Програми розвитку малого і середнього підприємництва було передбачено в міському бюджету на 2017 рік 300000 грн на фінансову підтримку, а саме на відшкодування суб'єктам підприємницької діяльності плати за користування кредитами. Згідно звітів виконання даної Програми кошти на такий захід використані не були, адже на розгляд відповідної конкурсної комісії не було направлено жодного проекту, тобто використання коштів становить 0\% від передбачених на рік.

Порядок часткової компенсації відсотків в місті Вінниця хоча і почав діяти у 2018 році, але за інформацією зі Звіту щодо показників результативності впровадження Порядку за I півріччя 4-и суб'єкти господарювання видано кредити на суму 3924 тис. грн в рамках даного механізму компенсації, 2-а з яких згідно рішень виконавчого комітету визнані учасниками процедури компенсації. За цей період у учасників процедури компенсації зросли як обсяги сплачених податків до міського бюджету, так і робочі місця на підприємствах [5]. Згідно інформації на офіційному сайті перше підприємство - учасник процедури компенсації отримає відшкодування згідно відповідного рішення виконавчого комітету у III кварталі 2018. Сума компенсації для підприємства ПрАТ «Вінницька харчосмакова фабрика», яке отримало кредит у розмірі 2000 тис. грн., склала 69,7 тис. грн. і становить 90,8\% від суми сплачених відсотків за користування кредитними коштами у II кварталі 2018 року.

В місті Кропивницькому за результатами 2017 року на часткову компенсацію відсотків за кредитами суб'єктам МСП на реалізацію інвестиційних проектів було виділено кошти в сумі 100000 тис. грн. Згідно процедури та механізму надання фінансової підтримки за рішенням Координаційної ради 3 питань розвитку підприємництва, яка здійснює відбір на конкурсних засадах проектів, у 2017 році було профінансовано тільки один проект «Відкриття цеху по виробництву крупи» товариства 3 обмеженою відповідальністю «Восход-86» на суму 16000 грн., тобто обсяг використання коштів становив 16\%. У І кварталі 2018 року кошти на фінансову підтримку витрачені не були, хоча у міському бюджеті Кропивницького на 2018 рік на компенсацію відсотків передбачено 150000 грн.

Серед усіх розглянутих механізмів найефективнішим можна вважити фінансову підтримку у вигляді відшкодування витрат за участь у виставково-ярмаркових заходах в місті Чернігові. Так на Програму підтримки малого та середнього підприємництва у м.Чернігові було передбачено на 2017 рік 981790 грн., а виконання складає 803330 грн., тобто 81,8\%, з яких 147400 грн. було використано на фінансову підтримку. Механізмом відшкодування витрат скористались 5 підприємств протягом 2017 року.

Висновки. В досліджуваних містах діють механізми стимулювання розвитку малого та середнього підприємництва, які пов'язані в першу чергу з компенсацією фінансових витрат по кредитах. Варто зауважити, що такі механізми впроваджуються протягом нетривалого часу та муніципалітетам доцільно більше уваги приділяти промоції можливостей отримання фінансової підтримки серед МСП. 3 іншого боку, наявний ризик невідповідності суб'єктів попереднім умовам участі та важкість 
виконання усіх критеріїв конкурсу (участі) у механізмах фінансової підтримки, особливо в Вінниці, Рівному, Кропивницькому. Варто також наголосити на недостатньо прозорому механізмі визначення переможців конкурсних відборів в містах, де він регламентується. Крім того, присутній фактор обмеженості можливостей малого підприємництва залучати кредити банків з огляду на вартість кредитних коштів та високий рівень ризику для МСП. За період впровадження найрезультативнішими $\epsilon$ механізми фінансового стимулювання розвитку МСП, що впроваджуються у місті Вінниця та місті Чернігів. Цікаво що цілі запровадження таких механізмів $є$ різні, у Вінниці - спрощення доступу до банківського кредитування та здешевлення кредитів на розвиток бізнесу, у Чернігові - стимулювання до виставково-ярмаркових заходів місцевих підприємців. Такі результати можна пов'язувати як із важливістю дотримання вимог прозорості при формуванні механізму фінансового стимулювання МСП у Вінниці, так і з точним визначенням окремої цільової аудиторії серед підприємців міста із запитом на промоційні заходи, зокрема для підприємств-експортерів.

\section{Література:}

1. Господарський кодекс України: Закон України від 16.01.2003 № 436-IV iз змінами, внесеними згідно із Закону від 18.01.2018 № 2269-VIII. [Електронний ресурс]. - Режим доступу: http://zakon3.rada.gov.ua/laws/show/436-15.

2. Про розвиток та державну підтримку малого і середнього підприємництва в Україні: Закон України від 22.03.2012 № 4618-VI. [Електронний ресурс]. - Режим доступу: http://zakon3.rada.gov.ua/laws/show/4618-17.

3. Про державну допомогу суб'єктам господарювання: Закон України від 01.07.2014 № 1555-VII. [Електронний ресурс]. - Режим доступу: http://zakon5.rada.gov.ua/laws/show/1555-18.

4. Офіційний сайт Державної служби статистики України [Електронний pecypc]. - Режим доступу: http://www.ukrstat.gov.ua/ .

5. Офіційний сайт Вінницької міської ради [Електронний ресурс]. - Режим доступу: http://www.vmr.gov.ua/

6. Офіційний сайт міської ради міста Кропивницького [Електронний ресурс]. Режим доступу: www.kr-rada.gov.ua/

7. Офіційний сайт Рівненської міської ради [Електронний ресурс]. - Режим доступу: www.city-adm.rv.ua

8. Офіційний сайт Чернівецької міської ради [Електронний ресурс]. - Режим доступу: www.chernivtsy.eu/

9. Офіційний сайт Чернігівської міської ради [Електронний ресурс]. - Режим доступу: www.chernigiv-rada.gov.ua/

10. Офіційний сайт Національного банку України [Електронний ресурс]. Режим доступу: https://bank.gov.ua/doccatalog/document?id=67591193

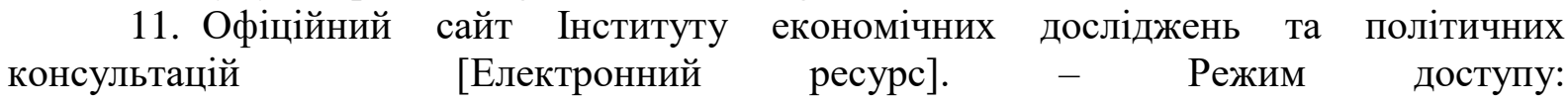
http://www.ier.com.ua/ua/areas_of_

research/business_climate?pid=5965 